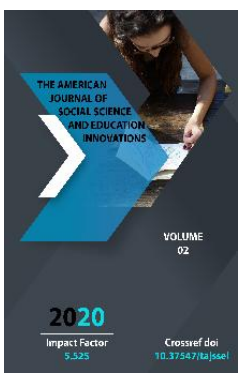

\title{
Moral Issues Of Upbringing A Person In A Healthy Spirit
}

Journal Website: http://usajournalshub.c om/index,php/tajssei

\author{
Allayarova Marhabo Mavlanovna \\ Candidate Of Philosophical Sciences, Associate Professor, Samarkand State University, \\ Uzbekistan
}

\section{ABSTRACT}

The scope of work in the field of education, which plays a key role in raising a healthy and harmoniously developed generation, is growing in our country. In this regard, one of the important conditions for achieving this task and forming young people as harmoniously developed people is their education in a healthy spirit. Only a nation brought up in a healthy spirit, having its own national spirituality and culture, can preserve itself as a people, a nation. An important task of state policy is the formation of a high moral and spiritual maturity, a perfect person, a healthy generation, and the preservation of the purity of the nation based on the education of a healthy spirit of youth. This article is devoted to the study and analysis of this task.

\section{KEYWORDS}

Criteria, development, education, education, healthy generation, morality, purity of the nation, sound mind, spirituality.

\section{INTRODUCTION}

Today, humanity has undergone tremendous changes, development factors and scientific achievements. His consciousness, his thinking aspires to infinity and exaltation. Unfortunately, as consciousness and thinking improve, various vices in human spirituality, as 
well as vices and destruction aimed at disrupting the lives of others, continue. The youth of the twenty-first century live in the midst of growing aggression of various ideologies and spiritual threats. As President of Uzbekistan Sh. Mirziyoyev noted: "We are doing a great job of educating young people who think independently, have modern knowledge and skills, have a strong life position... What a fierce struggle for the minds and hearts of the population, especially young people, is today around the world. Given the growing threats of religious extremism, terrorism, drug addiction, "mass culture," we must raise our children to a new level, without weakening our work in the field of spiritual education. We can say that this is, in fact, an eternal struggle between the confrontation between good and evil. On the other hand, man is a victim of the eternal struggle between these two poles. He is already aware of this struggle between good and evil in the world, but when he realizes, unfortunately, he himself has become an active participant in this struggle, ready to destroy each other, leading each other to decline. The destructive ideas created by man can destroy the earth more than once. Since we live in such a dangerous, dangerous world, we must first realize that we are human and that life is a great blessing for us. We must be able to see every threat to the spiritual life of our youth and be aware of it [1]."

\section{MATERIALS AND METHODS}

Today, human life is threatened by the evil it has created. In particular, we must carefully educate our children, who have not yet strengthened, in order to protect them from the onslaught of destructive forces affecting the media, using the psychological forces of art [2]. After all, they are the future owners of our future, our current development. In fact, this is an eternal struggle of opposites, good and evil. On the other hand, man is a victim of the eternal struggle between these two poles. He has already realized this struggle between good and bad in the world, but when he realizes, unfortunately, he himself has become an active participant in this struggle, ready to destroy each other, leading each other to decline. The destructive ideas created by man can destroy the earth more than once. Since we live in such a dangerous, dangerous world, we must first realize that we are human and that life is a great blessing for us. We need to be able to see every threat to the spiritual life of our youth and live with that awareness.

The scope of work in the field of education, which plays a key role in raising a healthy and harmoniously developed generation, is growing in our country. In this regard, one of the important conditions for achieving this task and forming young people as harmoniously developed people is their education in a healthy spirit. Especially important was the creation of the Youth Union on June 30, 2017, in our country and the declaration of this day as Youth Day. This set the main direction in the physical and spiritual development of young people, strengthening the health of the population, increasing their intellectual potential, training promising personnel, and forming a sense of love for the Motherland. It is important to teach them to solve this problem in a healthy spirit. Only a nation brought up in a healthy spirit, having its own national spirituality and culture, can preserve itself as a people, a nation. Accordingly, the formation of a high moral and spiritual maturity, a perfect person, a healthy future generation, the preservation of the purity of the nation based on the education of a healthy spirit in our youth is an important task of state policy. 
This, in turn, requires a deeper study of the essence of the concept of education in a healthy spirit. First of all, the essence of the concept of "Spirit" is defined in the "Explanatory Dictionary of the Basic Concepts of Spirituality" as "a reflection of being as a concept that actively reflects an objective world characteristic not only of man but also of animals, plants and even the inorganic world". "Active perception is literally human, and this perception is called spirit. The activity of the spirit is seen in the fact that it reflects reality in an orderly way, and not as it is". It should be noted that in this definition the essence of the soul is usually illuminated, and a clear definition is not enough. While modernity was studied by representatives of existentialism, one of the philosophical movements that believe that "the soul arises from the existence of the will", personalistic existentialism includes spirit: understanding, duty, conscience, compassion, honour, justice, sincerity, repentance, etc. [4].

But the doctrine of mysticism, which nurtured the purity of the human soul and studied it, at one time put forward the idea of a perfect man as a philosophical doctrine that served to harmonize the purity of the soul, heart and body. It is emphasized that the purity of the soul, heart and body contributes to the education of the purity of the soul. For example, in the source of the Islamic Encyclopedia: "Sufism, Sufism is a doctrine leading to spiritual and moral perfection in Islam" [5], the philosopher Abdulhai Abdurakhmanov "Sufism is a concern for humanity, serving with compassion and love, sincerity, sincerity. and wisdom. The purity of the heart (we emphasize a healthy spirit), the height of enlightenment and practical righteousness are the requirements of mysticism, and... this is a beautiful state"[6].
The spiritual world is a collection of moral events and processes related to the inner world of man. They are interrelated, diverse and complex and include spiritual and spiritual needs and interests, such as knowledge of the outside world and self-expression through culture, art and activity; ideas and knowledge about nature, society, man and himself; feelings; abilities, goals, interests, worldviews, beliefs and values [4].

Although there is mutual harmony between the concepts of spirit and the spiritual world, there is a difference when we talk here about the spiritual world of man, many psychologists conduct a lot of research on this issue. In this issue, we talk about the status of a person in which the spiritual world of a person is formed in his inner world, in his inner experiences, which are inseparable from his worldview. That is, the mental world of a person manifests itself in aggressive and nonaggressive states. The more a person grows up and is raised in destructive ideas, the more he grows up in this environment, the more his fetus, the result is a person in an unhealthy state of mind [7].

A person can have a healthy spiritual world only if the spiritual world is raised, grown and formed by healthy ideas. The basis and criterion for the formation of a healthy spirit is morality and spirituality. More precisely, a healthy soul consists of the main categories of moral principles, such as conscience, religion, justice, mercy, humanity, compassion, kindness, love, patriotism, responsibility, and is its spiritual dimension (the word "spirituality" in Russian means "spirituality"). Despite the fact that it is translated into Uzbek, it does not have as wide a meaning as in Uzbek! [3].) 
In the essence of the above definitions, it can be said that education in a healthy spirit means, in a broad sense, actions based on mental maturity, the harmony of the heart and mind, based on strict laws established by society and regulated by correct and moral ideas about the factors that affect the human spirit. to be shown to be oriented towards the idol, to the intellectual potential, to the idolatry of beliefs and will, which are imbued with justice and truth. At the same time, it is necessary to understand the education of the human mind and heart, thinking, the inner world, based on impeccable ideas, the principles of good and humanity. Based on these features, a healthy human psyche and a spiritual world are formed. These aspects shape and develop the basic requirements of mankind, called morality and spirituality. In particular, the creation of the "Youth Union" to encourage and support youth in various fields in the implementation of state youth policy in our country, the establishment of the state award "Mard o'glonlar", the medal "Kelazhak Bunyodkori", the prize "Zulfia" can be said that our choice is a practical expression of the formation of a healthy psyche in young people [8].

\section{CONCLUSION}

In short, educating young people in a healthy spirit is important to prevent or combat the various spiritual and ideological aggressions that threaten peace today. Raising young people in a healthy spirit is an important condition for the formation of high moral and spiritual maturity, a perfect person, a healthy generation, and the preservation of the purity of the nation. In addressing this problem, great attention should be paid to the use of propaganda methods through the media, fiction, art and all its forms, as well as the implementation of measures and the introduction of noble and progressive ideas, and spirituality should be its main criterion in such events.

\section{REFERENCES}

1. Mirziyoyev Sh. M. (2017). Together with our brave and noble people, we will build our great future. Tashkent. Uzbekistan, 488, p. 20.

2. M. Allayarova. (2020). The place of art in the structure of the spiritual system and its place in the interpretation of aesthetic thought. Falsafa va hayot, p.p. 8-12.

3. Ma'naviyat asosiy tushunchalar izohli lug'ati (In An interpretive dictionary of the basic concepts of spirituality.). dict. (2010). Tashkent. G'afur G'ulom. , p. 497.

4. Falsafa qomusiy lug'at (Philosophical encyclopedic dictionary.). Tashkent. Sharq. 2014, p. 447.

5. Islom entsiklopediyasi (Islamic Encyclopedia). (2017). State Scientific Publishing House "National Encyclopedia of Uzbekistan". ISBN: 978-9943-07-398-2, p. 456.

6. A.Abdurahmonov. (2004). Saodatga eltuvchi bilim(Knowledge Leading to Happiness). Tashkent, Movarounnahr, p.339.

7. Kushanova M. (2020). Psychological mechanisms of aggressive behavior in teenagers. Journal of Psychosocial Rehabilitation, Vol, 224, Issue 04.

8. Mirziyoyev Sh. M. (2017). We will resolutely continue our path of national development and raise it to a new level. Tashkent, Uzbekistan., p. 535. 
9. Allayarova, M., \& Nurmatova, U. (2018). Nekotorye voprosy formirovaniya esteticheskogo otnosheniya cheloveka $\mathrm{k}$ prirode. (The formation of a persons aesthetic relationship to nature). Aktual'nye nauchnye issledovaniya $v$ sovremennom mire, (3-4), 137-140. URL: https://asue.am/upload/files/aystex.pdf\#p age $=138$ 